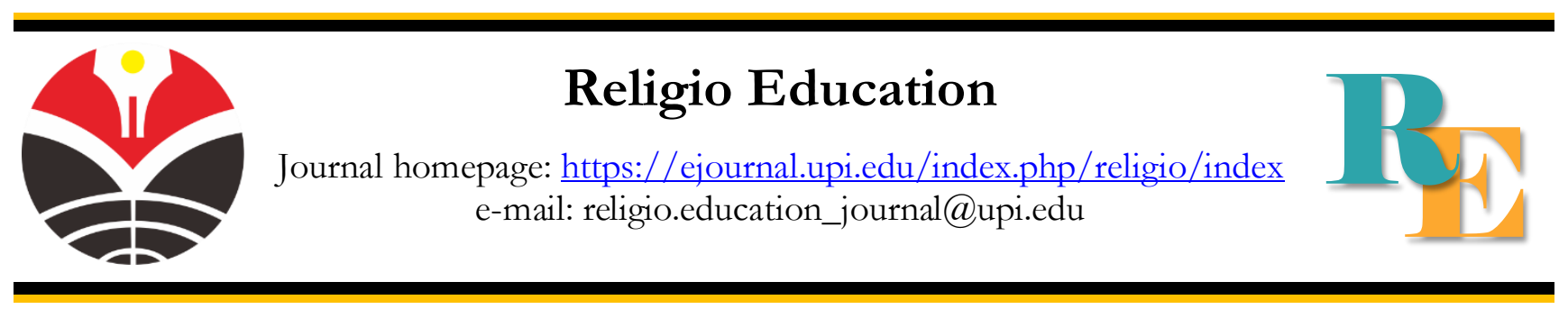

\title{
WORD EXPLORATION AND THE MEANING OF EVALUATION IN THE HOLY QURAN (THEMATIC INTERPRETATION OF EDUCATION EVALUATION)
}

\author{
Anwar Taufik Rakhmat* \\ Universitas Siliwangi, Tasikmalaya, Indonesia \\ anwar.taufikr@unsil.ac.id \\ Ari Farizal Rasyid \\ Universitas Siliwangi, Tasikmalaya, Indonesia \\ ari.farizal@unsil.ac.id \\ *Correspondence: anwar.taufikr@unsil.ac.id
}

\begin{abstract}
A b s tracts
This study is intended to find the meaning of education evaluation in an Islamic perspective studied through the Holy Quran. By using a qualitative approach, content analysis research methods and data analysis techniques with the maudhui interpretation, it is found that the meaning of evaluation in the Holy Quran is found in words which mean evaluation in the form of terms derived from the words, حَسَبَ, نَظَرَ, بَََا and إِتَنَحنَ totaling 150 verses. Of the four words in the Holy Quran, the researcher defines educational evaluation as "a series of systematic and integrative activities in the educational process carried out by the evaluator (the subject of evaluation) to the evaluation (the object of evaluation) to obtain a description of the results of achievement and recommendations for the educational process undertaken." Its activities include data collection, data interpretation, and decision making.
\end{abstract}

Article Info

\author{
Keyword: \\ Alquran; \\ Education; \\ Evaluation; \\ Islam; \\ Tafsir.
}

Article History:

Received 18 Jan 2021

Revised 15 Feb 2021

Accepted 04 Apr 2021

Available online 15 Mei 2021

\section{Introduction}

Evaluation is a part of the education component which has an important role in the process. Evaluation requires efforts to determine the extent to which educational goals are achieved from predetermined educational goals. One of the main components that must be understood by teachers in the learning process is evaluation. This means that evaluation is considered important and strategic because the results of the evaluation relate to all parties such as teachers, students, parents, government, and the wider community (Arifin, 2010, p. 1).

There are several things that become the background of the problem in research on the evaluation of Islamic Education. Empirically there are several problems that arise, namely, 1) Implementation of Islamic Education in schools is less attractive, less creative, tends to be monotonous, and saturating. 2) The implementation of the PAI evaluation is often monotonous 
and tends to focus on memorization and is oriented towards students' cognitive abilities. 3) The ability of Islamic Education teachers to carry out effective, efficient, creative and innovative evaluations is still lacking. 4) Gaps and mismatches of the results of the PAI evaluation with the students 'abilities and the realities of students' daily lives.

Empirically, the existing problems in evaluating Islamic Education are: 1) the concept of PAI evaluation in PAI books is still not getting enough attention and is very limited. 2) There is no conceptual formulation regarding the evaluation of PAI that is scientifically recognized and can be practically implemented. 3) there is no conceptual formulation of evaluation that has been studied and developed based on Islamic teaching sources. 4) Al-Qur an Islamic teachings have not been optimally used as a source and theoretical basis for the development of the Evaluation of Islamic Religious Education. To find solutions to the above problems, the authors compile this research with a research focus to find the words and meanings of the evaluation of education in the Holy Quran as part of the development of the concept of Islamic education.

\section{Methods}

This study uses a qualitative approach, which has natural characteristics (natural setting) as a direct, descriptive data source, process is more important than results, and analysis in qualitative research tends to be carried out by inductive analysis and meaning is essential (Sugiyono, 2010, p. . 8). This research uses documentation study method or content analysis. Content analysis is a research that is in-depth discussion of the content of written information. Text analysis must have its own methods and approaches that adapt to the type and characteristics of the text to be studied. The text examined in this study is Al-Qur'an. Therefore, the method of content analysis in this study is operationalized by the method of interpretation, namely tafsir maudhu'i.

In this study, the primary data were verses related to the concept of learning evaluation

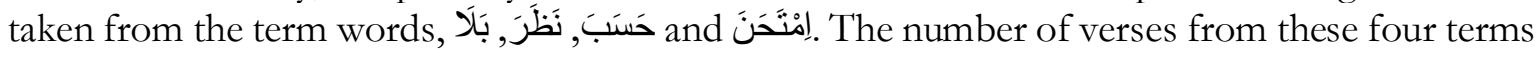
is 150 verses. Secondary data is supporting data for primary data, namely in this study a variety of literature related to the interpretation of the specified verse and books on learning evaluation. In general, the authors get this secondary data in the Maktabah Syamilah software program version 3.51, which contains more than 30,000 books of various books from various Islamic disciplines that have gone through the process of digitizing books. The researcher uses the book al-Mu'jam al-Mufahras li al-Fāz al-Qur ān al-Karìm by Muhammad Fu'ad Abd al-Baqy to trace

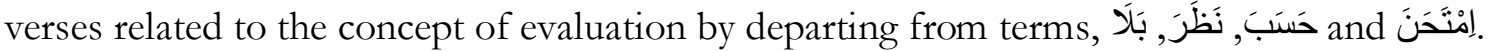

To guide the course of the research, the researcher formulated several problem formulations which include:

1. What are the words contained in the Holy Quran to mention the meaning of evaluation?

2. What is the definition of Educational evaluation developed from the word evaluation in the $\mathrm{Al}$-quran?

From the two problem formulations above, the researcher explores the text in the Holy Quran by using thematic interpretation techniques or maudhui in the Holy Quran. The research steps in this study followed the directions and guidelines for the maudu'i interpretation method developed by Al-Farmawi (2002, p. 51), then developed it by quoting and adapting some of the research steps of Aam Abdusaalam's (2011, p. 125) dissertation research. ). As for the research steps are as follows: 1) Determining the problem to be discussed, 2) Establishing letters and verses, 3) Collecting and compiling verses according to the order in which the letters were descended with knowledge of asāb al-nuzulnya, 4) Tracking the original linguistic meaning for each key word in the verse concerned, 5) Analyzing the interpretation of the previous interpretations, 6) Examining the balagiyah aspects that appear, 7) Looking for other verses and 
hadiths as explanations that can interpret the verse being studied, 8 ) Determine the author's attitude towards existing interpretations, 9) Conclude studies and interpretations, 11) Draw the concept of education according to the research topic.

\section{Results and Discussion}

\section{Evaluation Words in the Holy Quran}

The word Al-Qur'an according to Arabic has various meanings, one of which is reading or something that must be read, studied. Al-Qur'an is the word of Allah which is miraculous in nature that was sent down to the Prophet Muhammad SAW through the intermediary of Jibril with the pronunciation and meaning from Allah SWT, which was recited mut Worried; reading it is worship; starting with surah al-Fatihah and ending with surah an-Nas (Shihab, 2008: 13).

The Holy Quran is a source of Islamic teachings that are believed to be the source of the values and rules of human life. Can not be separated in it regarding education. Educational Evaluation is an important component of education to be assessed in order to obtain a complete and comprehensive concept of education. The Holy Quran is believed to be able to provide inspiration for meaning and guidance in the development of this educational evaluation concept.

In this study, the findings obtained are a study of the verses of the Al-Quran which have the meaning of evaluation. In the process of searching the data, the researcher determined

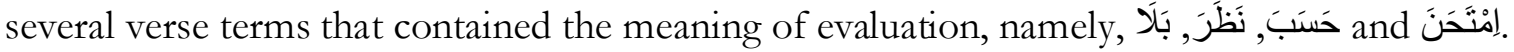

The verses containing these terms are inventoried and grouped according to the order of the letters and and the derivations of the words contained in the term. In searching for this verse, the researcher used the book al-Mu'jam al-Mufahras li al-Fāz al-Qur`ān al-Karīm by Muhammad Fu'ad Abd al-Baqy. After the data was collected, the researchers arranged them according to the chronological order in which the letters were descended. Regarding the descending list of the researchers' letters using an arrangement compiled by Muhammad Izzat Daruzah in his book entitled al-Tafsīr al-Hadîs.

Table 1.1 Recapitulation of Number of Evaluation Verses

\begin{tabular}{|c|c|c|}
\hline Numb. & Words & Number of Verses \\
\hline 1 & يَبْلُوَ - بَلَا & 37 \\
\hline 2 & حَسَبَ- يَحْسَبُ & 49 \\
\hline 3 & يَنْظُرُ - نَظَرَ & 62 \\
\hline 4 & أَمْتَحَنَ- يَتْحِحنُ & 2 \\
\hline 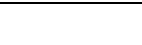 & mount & 150 \\
\hline
\end{tabular}

With this number of verses, the researcher would have had difficulty if he studied all the verses in depth. Therefore, the researcher selects these verses until only a few verses are chosen to be used as verses to be studied for discussion in the research. The things that are used as a means of consideration (instruments) in determining the verses to choose are the following: 1) the literal (lexical) meaning of the word chosen, 2) the correlation of the context of the verse with the specified theme, namely educational evaluation, 3) representation of several the same verse in one term and one word derivation.

From the verse data found, the next researcher analyzed the verse by following the procedures, steps and verse analysis techniques as previously stated. Guided by the formulation of the problem that has been determined, the researcher gets the concept formulation of the word and the meaning of the evaluation of education in the Holy Quran. 


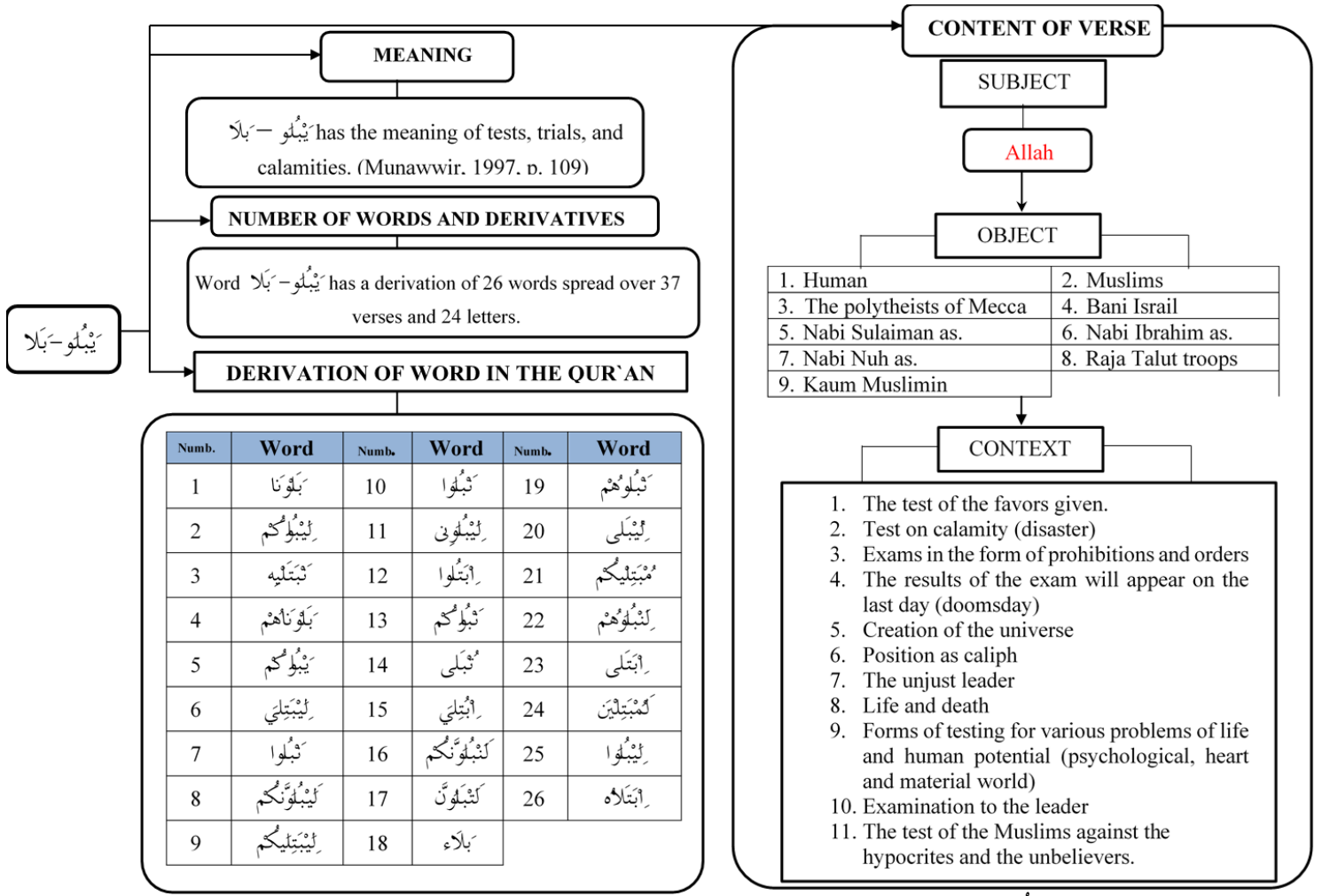

Figure 1. Picture Words and Meanings of the term بَلَ-يَنْلُ

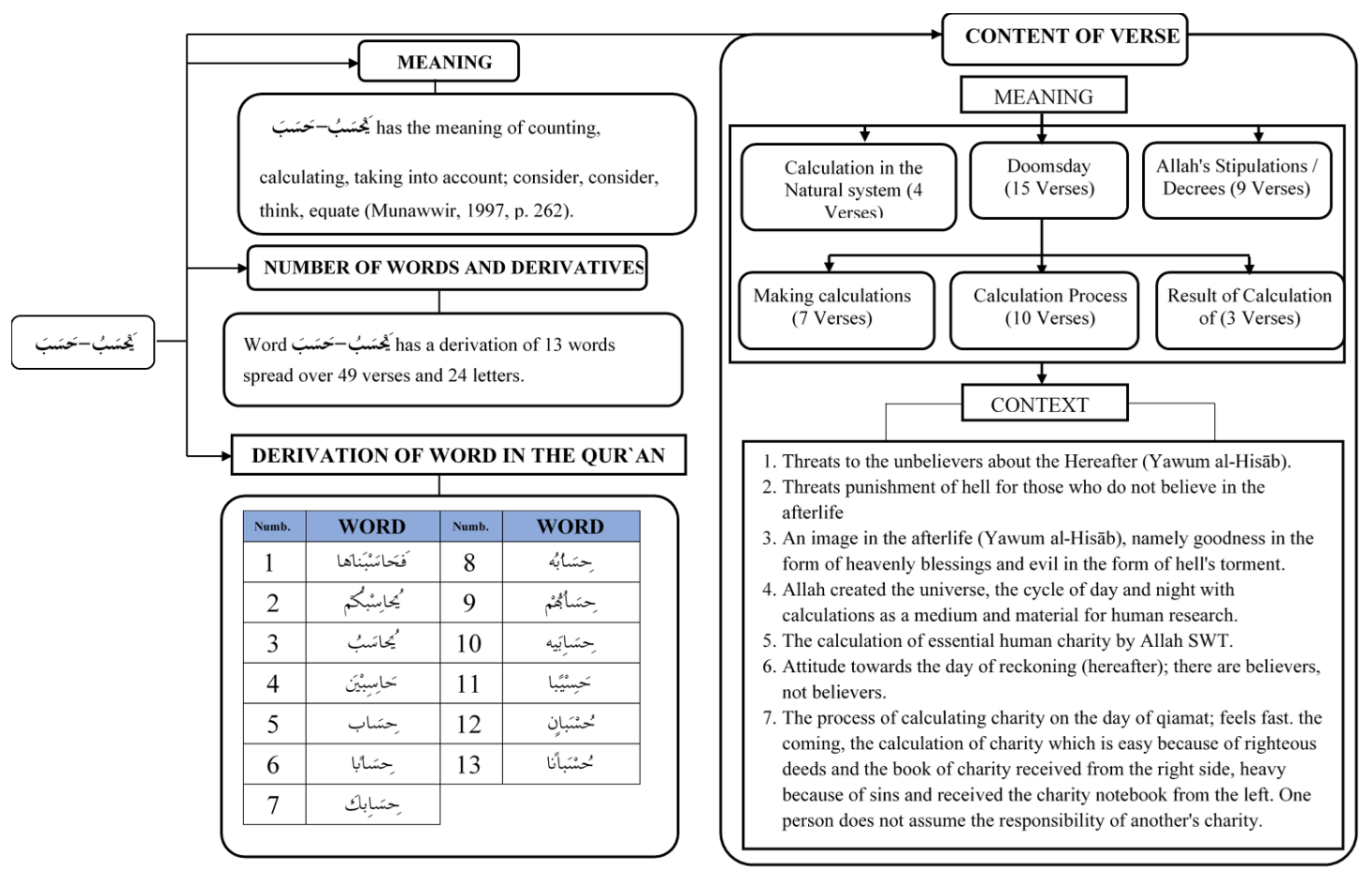

Figure 2. Picture Words and Meanings of the term يُسَبُْ-حَسَب 


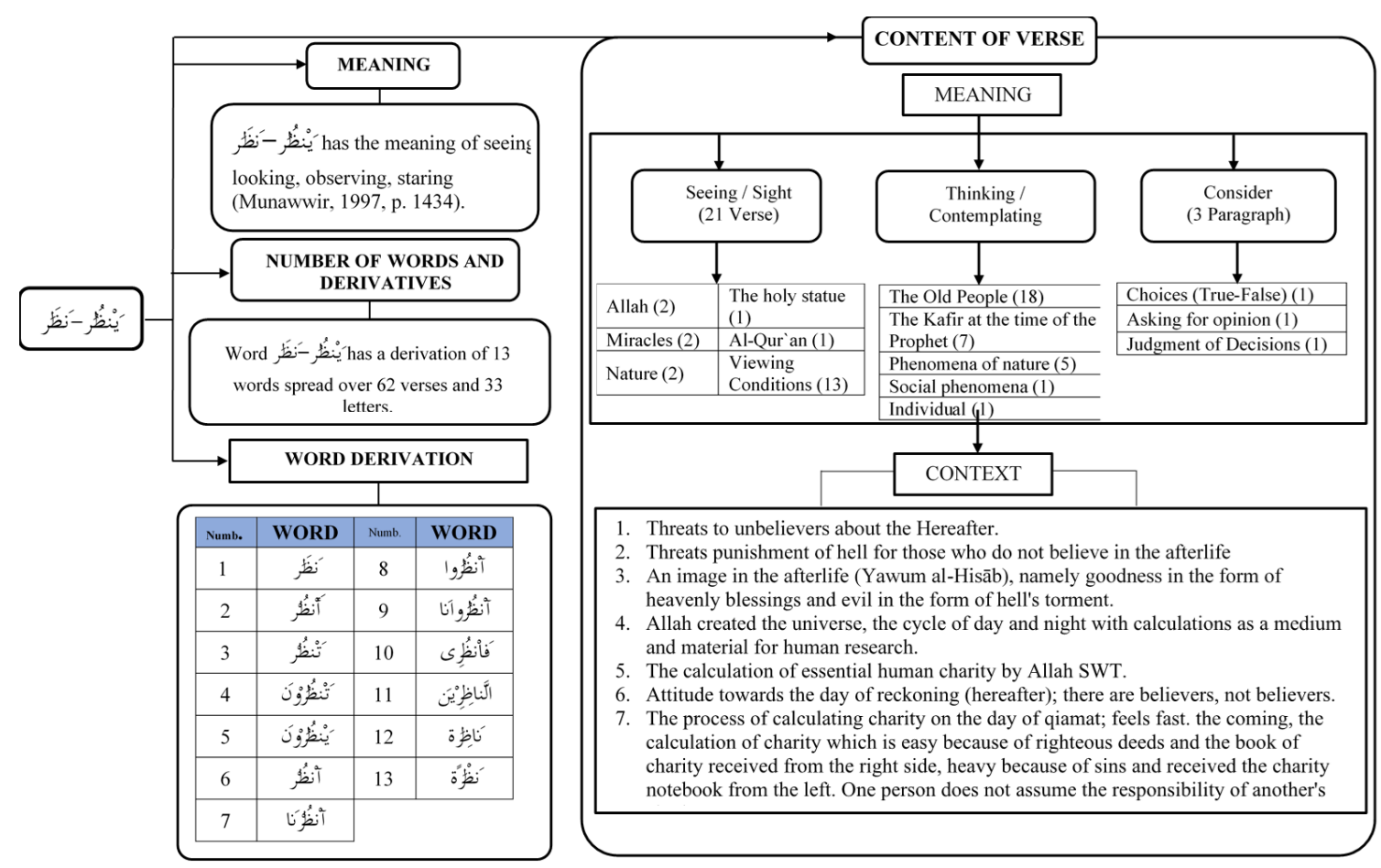

Figure 3. Picture Words and Meanings of the term يْظُرُ-نَظَ

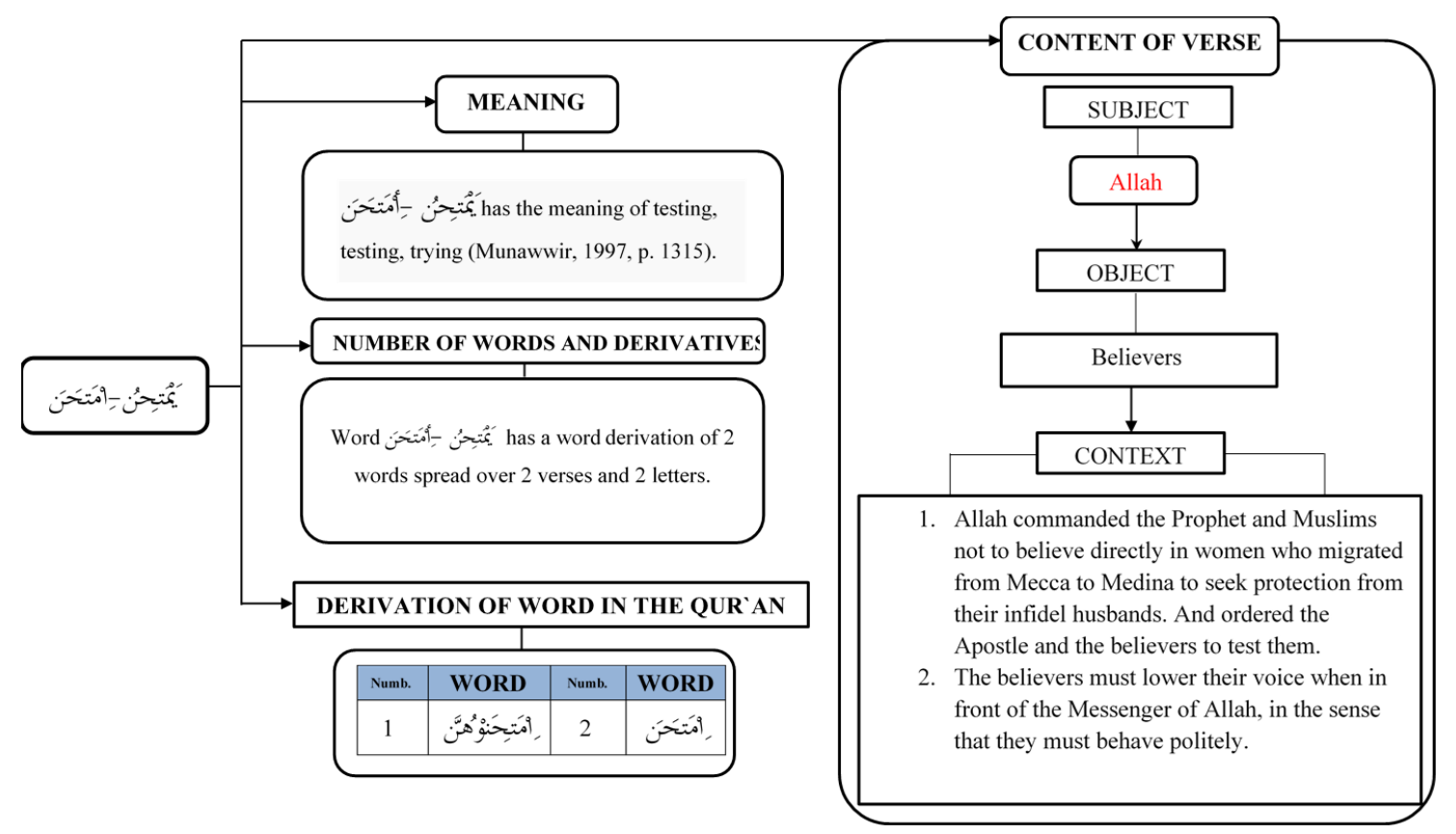

Figure 4. Picture Words and Meanings of the term يُتَحِنُ-إِتَحَحَن

\section{The Meaning of Educational Evaluation in the Holy Quran}

Based on the findings of verses in the form of evaluation verses based on the terms

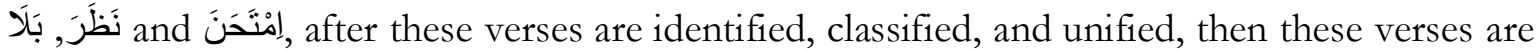
presented in a discussion in the form of conceptual formulations regarding educational 
evaluation, using the formula the problem that has been determined in this study, namely to produce a definition of the evaluation of education in the Holy Quran.

The definition in the Big Indonesian Dictionary (Tim Penyusun KBBI, 2008, p. 330) is defined as "a word, phrase, or sentence that expresses the meaning, description, or main characteristic of a person, object, process, or activity; limit (meaning) ". Every concept in scientific construction requires a definition as an identity and meaning about itself. Thus, the definition is mandatory and must be understood together between concept builders and users.

The general definition is to talk about the boundaries of a concept and identity about something. Evaluation as a concept is absolutely built from a definition. Therefore in this study formulate a definition of educational evaluation as a starting point in its discussion.

As stated in the research findings, the researcher defines educational evaluation in the perspective of the Qur'an as "a series of systematic and integrative activities in the educational process carried out by the evaluator (the subject of evaluation) to the evaluation (the object of evaluation) to obtain a description of the results of activity achievement. undertaken and recommendations for the education process to make it better. Its activities include data collection, data interpretation, and decision making. "

The following is a discussion of the definition of educational evaluation above based on the verses found and their discussion. The phrase "a series of activities in the educational process carried out by the evaluator (the subject of evaluation) to the evaluator (the object of evaluation) to obtain a description of the results of the activity carried out" is revealed from the discussion of the paragraph below.

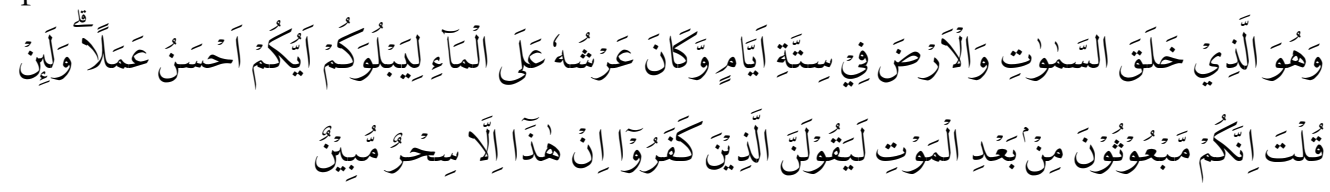

It is He Who created the heavens and the earth in six ages, and is His throne (before that) above the water, that He might test which of you is better at doing good, and if you say (to the people of Mecca): will be resurrected after death ", surely those who disbelieve will say:" This is nothing but real magic ". (Hūd [11]: 7)

In the letter Hūd [11] verse 7 above there is the word yabluwakum which means testing. The word is a form of the verb (fi'il / verb). Fi'il in Arabic is a form of word that shows a certain job or activity and contains time in it. (Shihab M. Q., 2013, p. 53) Every verb (fi'il) must have a subject who does the work (fā'il) both implied and express (Anwar \& Bakar, 2012). Fā'il in the fi'il is Allah, which can be known through zamir gaib wahdah which is contained in the word yabluwakum.

From the phenomena of the text of this verse, it can be understood that Allah as an evaluator (the subject of evaluation) gives a test / evaluation to humans as an evaluation (object of evaluation) in the form of the creation of the universe (evaluation material). Why did Allah do this? Because to find out who is good at charity and this is the goal of giving the exam.

Based on the science of șaraf, yabluwakum is fi'il mu yangari which muta'addi to two maf'ùl (verbs that require two objects). The first object is the inhabitants of Mecca, the second is the creation of the heavens and the earth.

In the book Tafsir Jalalain, the mufassir explains that the pronunciation of "liyabluwakum" means ta'alluq (related / related) to the pronunciation of "khalaqa" which means, Allah created the heavens and the earth and their contents, namely in the form of 
benefits and maslahat to test humans. So, in essence, everything in this universe is a test for humans.

The second object in the above verse arrangement is the creation of the heavens and the earth. The na in this verse shows that, Allah created the universe with everything in it is a test for mankind. Even though the khitab in this verse is a mekkah person, there is a rule of interpretation which states that العبرة بعموم اللفظ لا بخصوص السبب means legal stipulation based on the generality of lafa l, not because of specific reasons. Therefore, this verse can be understood that Allah created the heavens and the earth and their contents as a form of testing for all humans, not only for the inhabitants of Mecca at the time of the Prophet.

The phrase "to get better results" is taken from the study of the pronunciation of the

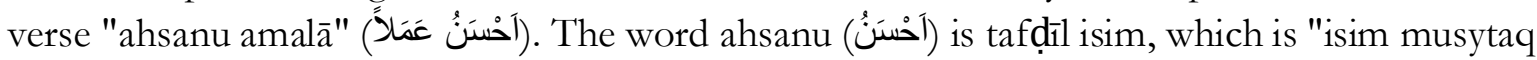
(word formation) which means" more "with the فعل wazan pattern for mużakkar and فعلى for mu annaŝs" (Hakim, 2004, p. 17). In simple terms this word shows a better meaning, the meaning of the above verse is that Allah tests humans by creating the heavens and the earth so that humans strive for better results of deeds (charity).

Isim tafdịl is a word that shows the meaning of exaggerating one party over another. From the above verse it does not mention mufadal 'alaih (which is exaggerated) and only mentions mufadal (which exceeds), namely your word (كم) damir (pronoun) which is contained in the

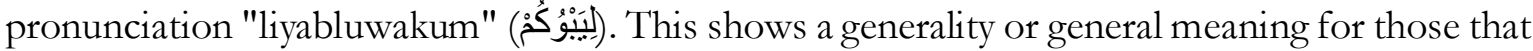
are exaggerated. On the basis of this understanding, the evaluative meaning can be taken, namely evaluation is an attempt to get better results from activities that have previously been carried out on him or from other parties.

Furthermore, the expression "the test is an effort to find out the results of what is given in the form of learning material" is taken from the editorial of the following paragraph:

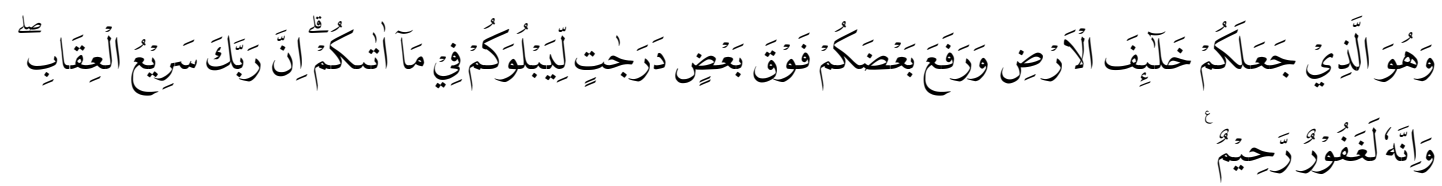

It is He who made you the rulers of the earth and He raised some of you over some (others) a few degrees, to test you of what He gave you. Surely your Lord is very quick to torment and Verily He is Forgiving, Most Merciful. (Al-An'ām [6]: 165)

The above verse affirms that Allah made man a caliph, and gave some advantages over others. With these advantages, Allah wants to test them, whether they are able to use the gifts Allah has given them for the path of obedience and seek the pleasure of Allah or make them deny and turn away from Allah. According to Al-Rāzì in his interpretation, there are three purposes of the caliph there, the first is the Messenger of Allah as the caliph because as the closing of the prophets and the leaders of the whole people, the second makes some people the caliphs over some other humans, and the third is the caliph who is the leader of a territory.

Ibn Kaŝīr explains that in the pronunciation "liyabluwakum fì mā àtākum", he means that Allah tests man for everything that is given to him. Allah created humans differently, some are excess in property, some are deficient in property, some are excess in position or so on (Surah al-Zukhrūf [63]: 32). Those who are given excess assets are tested with their abundant assets, and those who lack wealth are tested with their lack of assets. Allah will judge the extent of obedience to Him by what Allah has given, whether patient or not, grateful or not. 
From the explanation of the mufasir above, it can be understood that Allah will test what Allah has given, it is impossible for Allah to test something that His servants have never received.

Furthermore, the expression "evaluation is a systematic and integrated activity which includes data collection, data interpretation, and decision making in the educational process" is taken from the study of the following verses:

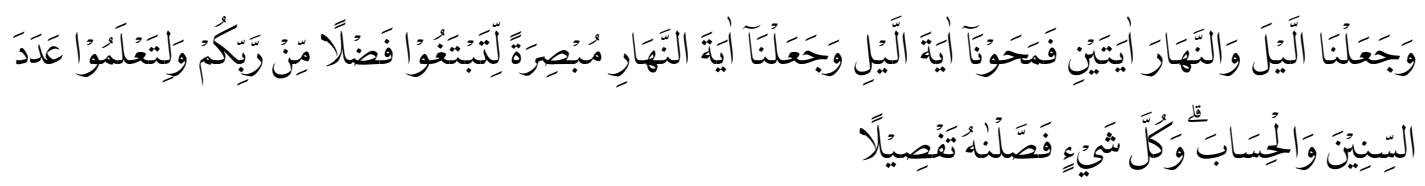

We made the night and day two signs, then We erased the sign of the night and We made the sign of the day light, that you may seek the gift of your Lord, and that you might know the number of years and the count. and everything We have explained clearly. (Al-Isrā’ [17]: 12)

Pronunciation in Al-Munawir's Dictionary (1997, p. 261) is defined as counting, calculating, calculating, considering, considering, thinking, likening, trying, and testing. while حسب Ahmad Ibn Faris Ibn Zakariya in his book Māqayis al-Lugah (tt) explained that the word has three basic meanings, namely 1) number / count, 2) sufficient / sufficiency, and 3) guessing / guessing. By considering the suitability with the research theme in this study, the researcher took a verse that contained the meaning of counting and did not use other words.

According to Shihab (2009b) The word hisāb originally meant counting. This word is then used in the Qur'an in the sense of "examining carefully everything that is the object of calculation, physically and mentally, without leaving anything behind. In Sura Al-Isrā ‘ $[17]$ verse 12 it is explained that Allah created day and night alternately as a sign of Allah's power and aims so that humans know the number of years and calculations. Can be noticed in the underlined word.

In the above verse there is a tremendous leap in meaning that shows a dynamic meaning. At the beginning of the verse Allah explains the verses that are Muhkam in nature, then followed by the verses that are mutasyabihat. The beginning of Allah's verse explains the phenomenon of night and day processes by mentioning the function of these natural processes. but at the end of the verse, Allah mentions the word الحساب which means calculation. Most of the many interpretations including al-Jalalaīn, Țabrāni, and al-Bayḍawi explain that hisāb here is a calculation of time or everything related to the calculation of human time. This can be understood because the word reckoning is in a series of natural phenomena that describe time on earth. However, if you pay attention to the continued verse كل شيء فصلنه تفصيلا Allah explains something very general, with the word كل شيء. Meanwhile, what is generally understood by Muslims is that Allah does not explain natural phenomena in full and clear detail, but only a few natural phenomena that are explained in the Al-Qur'an and become scientific signals for humans to study them more deeply.

There is another hisāb verse which explains the systematic and orderly elements and their relationship with the creation of the universe, namely Surah Yūnus [10] verse 5 which reads: 


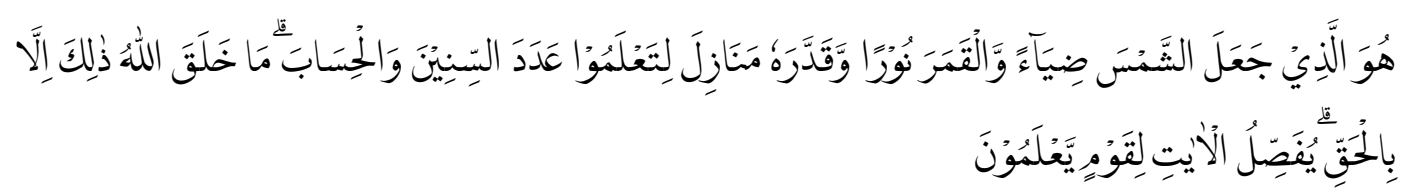

It was He who made the sun shine and the moon shine and He appointed manzilah (places) for the lunar journey, so that you would know the number of years and calculations (time). God did not create it but with such rights. He explained signs (His greatness) to people who knew. (Yūnus [10]: 5)

This verse further strengthens the meaning of the previous verse about Allah's command in managing this universe, by creating all celestial bodies with their respective places and paths, creating celestial bodies with their functions and positions.

From the study of the two verses above, the evaluative meaning that can be taken is that the overall evaluative process requires systematic and integrative principles. Systematic in the sense, the whole process occupies procedures and steps in accordance with what they should be and follows the rules in their implementation. The meaning of integrity here, at least there are two main things, the first is the integration between the evaluation components (subject, object, material, objective, principle, procedure, etc.) that must be integrated with the existence of Allah as the Creator. Because of all movements, strength and effort will not be separated from the permission and power of Allah. Second, the integration between the evaluation components (subject, object, material, objective, principle, procedure, etc.) must be realized into a solid, non-partial unit and in the same understanding and expectation.

Furthermore, the meaning of "the integrated nature of evaluation" from the definition of educational evaluation in the perspective of the Qur'an can be seen from the study of the verse below.

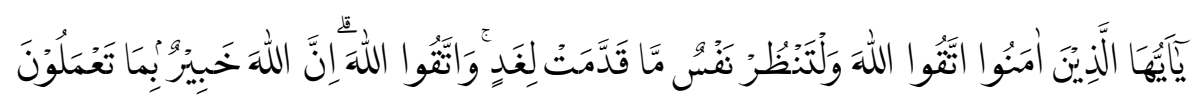

O you who believe, fear Allah and let each one pay attention to what he has done for tomorrow (hereafter); and fear Allah, Allah knows best what you are doing. (Al-Hashr [59]: 18).

Verses 18-21 of Surah Al-Hashr speak of the Jews and the hypocrites whose end they were tortured both worldly and heavenly. Verse 18 teaches Muslims to be careful not to suffer a fate like them. (Shihab M. Q., 2009c, p. 552)

In this verse Allah commands the believer to be obedient to Him, then followed by the word command to pay attention to what is inside for a better tomorrow (in the interpretation of Jalalain and most of the other interpretations it means the last day / end), then followed again the commandment to fear Him.

The meaning of 1 in the dictionary of Munawwir (1997, p. 1433) is defined as considering, examining, testing, studying. And according to Ahmad Ibn Faris Ibn Zakariya in

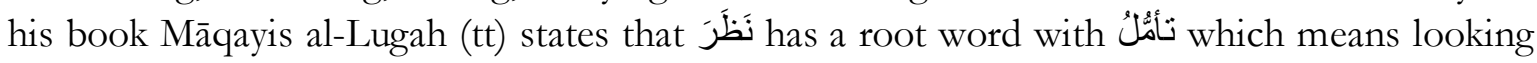
attentively, researching. Meanwhile, in the book Mu'jam al-Wasìt by Ibrahīm Mustafa et al (tt). نًََ is seeing with the eyes which is accompanied by the process of mind and heart namely tadabbur and tafakkur so that iَ نَ can be interpreted as reflecting, considering, contemplating, managing, taking care, maintaining and obtaining.

From this semantic study of the word it can be drawn the concept that evaluation in the Al-Qur'an from this verse, namely evaluation is a series of activities that include data 
collection, data interpretation, and decision making on the object of evaluation. Because in essence نََّ is not only limited to looking at objects by using the five senses alone, but in it there is a process of contemplation, consideration, research and up to the decision making regarding the visual process.

In the analysis of the sentence structure (kalam), the word ولتنظ means the command to evaluate, begins with the command word to fear Allah and ends with the command to fear Allah as well. From here we can see the evaluative meaning, that the evaluation process must begin in the sense that it is based on the intention and motivation of being devoted to Allah and ends with the goal of submitting to Allah.

In addition, in the study of balagah the above verse consists of four kalam arrangements (musnad - musnad 'alaih), the first three kalam diwașal (combined using the letter' ataf wau) while the last difașal kalam is combined without the letter 'ataf wau.

The fourth kalām is in fașal (combined with the previous kalām with no wașal/wau verbs) because it is the explanation (bayan) of the previous kalam (كََالُ الإتَِّّنَالِ), and has a strong connection as if it cannot be separated. While the first to third kalām are diwașal with the haraf 'ațaf, because they have the same type of kalam, namely kalām Insyà'i. This indicates the order in the kalām, the commandment to fear, the commandment to evaluate, and the commandment to fear. This explains that, in a series of evaluation processes, it is always based on devotion to Allah and does not give up Allah's existence as Rabb and Creator of the entire process, from the initial stage to the final stage of evaluation.

Then this becomes one of the main points in the discussion of educational evaluation in the perspective of the Qur'an and becomes a differentiator from evaluation with general perspectives. The perspective of the Qur'an requires that the entire evaluation process does not stop at the evaluation itself, but must present the existence of Allah in the whole process and its components (meaning integrative). What does it mean that the evaluation process and the results of the evaluation are going well and according to plan and satisfying all the stakeholders, but ignoring divine values? It seems that this is one of the reasons among many other causes that the evaluation of education in schools becomes like a charade and a deception between evaluators and evaluators.

Then the evaluative meaning of the repetition of the piety commandment and the flanking of the evaluation command between the two, is that in the evaluation process it should emphasize the actualization of piety to Allah or in other words the evaluation must be able to bring together the meaning of submission to Allah, not vice versa, namely keeping away from laughter to Allah. This is an integrative meaning in this definition of educational evaluation.

According to Shihab (2009c, p. 552) The use of the word nafs (self) which is singular from one side to indicate that it is not sufficient to assess some of the others, but each must do it independently of himself, and on the other hand he suggests that in reality this self-criticism is extremely rare.

From the explanation of Surah Al-Hasyr [59] verse 18, it can be concluded that evaluation, including educational evaluation, was ordered by Allah directly, to get a change for the better, by emphasizing the value of tauhid and ihsān in it. The point is that all evaluation activities from beginning to end, from planning to implementation must always be in an effort to actualize the value of piety to Allah SWT.

Finally, the editorial team of "Educational evaluation activities include data collection, data interpretation, and decision making" taken from the study of the verse below. Shaleh et al. 
(1993, pp. 516-517) explains that in a narration that came from al-Syaikhani received from alMiswār and Marwān bin al-Hakām it was stated that after the Prophet. made a treaty Hudaibiyah, came some women who believed from Mecca. So this verse came down, (Surah Al-Mumtahanah [60]: 10) which ordered to test the woman who had migrated first, and not to be returned to Mecca.

Regarding whoever the woman who came to emigrate to Medina, there are many narrations that explain it. Some have reported that the woman was' Umm Kulŝum Bint 'Uqbah Ibn Abī Mu'ait (narrated by T, Tabrani), Umaimah Bint Basyar, the wife of Hasan al-Dahdahah (narrated by Ibn Abì Hatìm) and the wife of' Umar Ibn Khaț̣āb who was still on the side of the Musyrikīn (narrated by Ibn Mani ').

It seems that Shihab (2009c, p. 603) prefers the last Hadith, namely the families of friends who emigrated to Medina, and some of their families are still in Mecca, because they have not embraced Islam. This verse instructs us not to have an intimate relationship with those who are hostile to Allah and His Messenger even though his own family.

In the Jalalain Interpretation, it is explained that the way to test the Messenger of Allah on migrating women is through oaths, namely that they do not leave their hometowns but because they are happy with Islam, not because they hate their husbands who are infidels, nor because they love people a man from among the Muslims. These are the contents of the oath made by the Prophet. to the women.

This incident was related to the Hudaibiyah agreement, namely the agreement between the Prophet and the polytheists of Mecca, one of which was that "the people of Mecca who came to visit Medina - even though they were Muslims - had to be returned by the Prophet to Mecca, while the people of Medina - even Muslims too - would join. the polytheists did not have to return to Mecca to Medina "(Shihab MQ, 2009c, p. 604).

From the explanation of the asbāb nuzūl verse above, it can be understood that this verse was revealed when the Hudaibiyah agreement was carried out, at which time a believing woman came from Mecca to Medina to ask for protection and ask for permission to stay in Medina. However, Rasulullah did not immediately accept him but was ordered to test his faith. Based on some of the history of the Prophet Muhammad tested it in a way that the woman had to take an oath and straighten out her intentions about her hijrah. After knowing the seriousness of her faith, the Prophet then stipulated a law according to Allah's word regarding the woman, namely that she had to break the marriage relationship with her husband who was still an infidel by returning the dowry given to her and then allowing Muslim men to marry her according to the terms of marriage.

From the context of this verse we can understand that everything that is stated regarding a person's faith must be known by others and tested. Even though faith is essentially God who knows, it still has to be born and known to others as stated in the interpretation of alZamakhsyari. He emphasized that the command to test faith in women who migrate does not mean that Allah does not know about their faith, but that the emphasis is on the birth effort that must be taken.

There are three things evaluative meanings that can be obtained from the description of the above verse, namely matters relating to three things, first, the Prophet sought about the truth of the faith of women who had migrated, second; checking and ensuring the truth about one's faith (even though in essence God knows someone's faith), and third; giving a decision to the woman was accepted by the Muslims in Medina and could not be returned to her husband who was an infidel and allowed a Muslim man in Medina to marry that woman. 
Of these three things inspire the evaluation activities that must be carried out, namely obtaining information related to the material provided, interpreting the data by knowing its truth and validity, then determining attitudes and decisions on the results of the data obtained. That is the definition of educational evaluation in the perspective of the Qur'an, which is excavated and developed from verses of the Al-Qur'an related to the theme of evaluation.

\section{Conclusion}

Evaluation of education in Islam which is extracted from the Holy Quran, it is found that there are four basic word terms, namely, إِْنَحَنَ and Each word with its derivation in the Holy Quran is scattered in 150 verses. By following the thematic study steps/maudhui in the interpretation of the Holy Quran, the formulation of the definition of education evaluation is "evaluation is a series of systematic and integrative activities in the educational process carried out by the evaluator (the subject of evaluation) to the evaluation (the object of evaluation) to obtain a description of the achievement results and recommendations for the educational process carried out. " Its activities include data collection, data interpretation, and decision making.

\section{References}

... (2010). Alquran. Syamil Al-Qur'an dan Tajwid: Dilengkapi Asbab al-Nuzul, Inti sari Ayat dan Hadis. Bandung: Sygma Examedia Arkanleema.

Abdullah, S. (2012). Evaluasi Pembelajaran; Konsep Dasar, Teori dan Aplikasi. Semarang: Pustaka Rizki Putra.

Abdussalam, A. (2011). Pembelajaran dalam Al-Quran Al-Karim (Studi Bayani terbadap Konsep Ta'lim dalam Al-Quran); Disertasi. Bandung.

Abdussalam, A. (2011). Pembelajaran dalam Al-Quran Al-Karim (Studi Bayani terbadap Konsep Ta'lim dalam Al-Quran); Disertasi. Bandung: Tidak Diterbitkan.

Al-Farmawi, A. H. (2002). Metode Tafsir Maudhu'i dan Cara Penerapannya. Bandung: Pustaka Setia.

Anwar, M., \& Bakar, A. A. (2012). Ilmu Nahwu (Terjemah Matan Jurumiyyah dan 'Imrity). Bandung: Algensindo.

Arifin, Z. (2010). Aplikasi Konsep Evaluasi dalam Pembelajaran PAI di Sekolah Dasar.

Hakim, T. (2004). Qäidati Program Pemula Membaca Kitab Kuning(:. Jepara: Al-Falah.

Moleong, L. (2002). Metodologi Penelitian Kualitatif. Bandung: Remaja Rosda Karya.

Munawwir, A. W. (1997). Al-Munawnir Kamus Arab-Indonesia. Surabaya: Penerbit Pustaka Progressif.

Mustafa, I., al-Aziyat, A., al-Qadir, H. '., \& al-Najar, M. (tt). Mu'jam al-Wasit. Majmu' al-Lugah al-'arabiyyah.

Rahman, A. (2007). Quranic Sciences (Ensiklopedi Ilmu dalam Al-Qur an; Rujukan terlengkap isyaratisyarat ilmiah dalam Al-Quran). (T. Rahman, Trans.) Bandung: Mizan Pustaka.

Salim, H. J. (2014, Mei 17). Mendikbud: Ada Oknum Kepala Sekolah Terlibat Kecurangan UN. Retrieved Januari 27, 2015, from Liputan 6 : http://news.liputan6.com/read/2050912/mendikbud-ada-oknum-kepala-sekolahterlibat-kecurangan-un 
Shaleh, Q., Dahlan, A., \& Dahlan, M. (1993). Asbabun Nuzul: Latar BElakang Historis Turnnya Ayat-ayat Al-Qurian. Bandung: Diponogoro.

Shihab, M. Q. (2007). Membumikan Al-Quran. Bandung: Mizan.

Shihab, M. Q. (2007a). Membumikan Al-Quran; Fungsi dan Peran Wabyu dalam Kehidupan Masyarakat. Bandung: Mizan.

Shihab, M. Q. (2007b). Tafsìr al-Misbāh (Vol. 1). Jakarta: Lentera Hati.

Shihab, M. Q. (2008). Tafsir al-Misbäh (Vol. 4). Jakarta: Lentera Hati.

Shihab, M. Q. (2009a). Tafsìr al-Misbāh (Vol. 7) (Vol. 7). Jakarta: Lentera Hati.

Shihab, M. Q. (2009b). Tafsir Al-Misbah (Vol. 9). Jakarta: Lentera Hati.

Shihab, M. Q. (2009c). Tafsìr al-Misbāh (Vol. 13) (Vol. 13). Jakarta: Lentera Hati.

Shihab, M. Q. (2013). Kaidah Tafsir. Tanggerang: Lentera Hati.

Sugiyono. (2010). Metode Penelitian Kuantitatif Kualitatif dan R \& D. Bandung: Alfabeta.

Tim Liputan 6 SCTV. (2014, April 15). Aksi-aksi Nyontek Saat UN yang Tertangkap CCTV. Retrieved 01 28, 2015, from Liputan6: http://news.liputan6.com/read/2037118/aksiaksi-nyontek-saat-un-yang-tertangkap-cctv

Tim Penulis Sie.Pengajaran Ponpes. Sukahideng. (2002). Ilmu Balagah. Tasikmalaya: Tidak diterbitkan.

Tim Penyusun KBBI. (2008). Kamus Bahasa Indonesia, Edisi Keempat. Jakarta: Gramedia Pustaka Utama.

Zakariya, A. I. (tt). Mãqayis al-Lugah. Ittihad al-Kitab al-'Arab. 